\title{
Sprouting and metabolism of sweet potatoes roots cv. BRS Rubissol during storage
}

\author{
Paula Cristina Carvalho Lima ${ }^{1} \oplus$, Mirelle Nayana Sousa Santos ${ }^{1} \oplus$, Fernanda Ferreira de Araújo ${ }^{1} \oplus$, \\ Jean Paulo de Jesus Tello ${ }^{1}$, Fernando Luiz Finger ${ }^{1}[0$

\footnotetext{
1 Universidade Federal de Viçosa, Departamento de Fitotecnia, Programa de Pós-Graduação em Fitotecnia, Viçosa, MG, Brazil. E-mail: paulinhahlima@yahoo.com.br; mirellebio@hotmail.com; fernandaufv@hotmail.com; jp_jt@hotmail.com; ffinger@ufv.br
}

ABSTRACT: Sprouting and mass loss in sweet potato tuberous roots stored at room temperature compromise the quality and commercialization; nevertheless, sprouting control methods are very limited. The objective was to evaluate the control of sprouting and metabolic changes in tuberous roots of sweet potato cv. BRS Rubissol treated with ethylene $\left(10 \mu \mathrm{L} \mathrm{L}^{-1}\right)$, amino-oxyacetic acid - AOA (1 mg L-1) and 1-methylcyclopropene - 1-MCP $\left(1 \mathrm{mg} \mathrm{L}^{-1}\right)$ during storage for five weeks at $25^{\circ} \mathrm{C}$ and $90 \%$ relative humidity. The following variables were evaluated: mass loss, number and length of sprouts, activity of peroxidase and polyphenoloxidase enzymes, total soluble sugars, starch, anthocyanins, flavonols, malonaldehyde content and total proteins. During storage the mass loss, number and length of sprouts were lower in roots treated with AOA and 1-MCP. The activity of peroxidase and polyphenoloxidase enzymes was higher in roots treated with ethylene. Total soluble sugars increased and the starch contents decreased in all treatments. Levels of anthocyanins and total proteins reduced, while flavonoids and malondialdehyde increased during storage. Sprouting was controlled in roots treated with $A O A$ and 1-MCP, extending shelf life and improving marketing potential.

Key words: carbohydrates; ethylene; Ipomoea batatas; root decay; sprout control

\section{Brotação e metabolismo de raízes de batata-doce cv. BRS Rubissol durante armazenamento}

RESUMO: A brotação e perda de massa em raízes tuberosas de batata-doce armazenadas à temperatura ambiente comprometem a qualidade e comercialização, ainda assim, métodos de controle de brotação são muito limitados. 0 objetivo foi avaliar o controle da brotação e alterações metabólicas em raízes tuberosas de batata-doce cv. BRS Rubissol tratadas com etileno $(10 \mu \mathrm{L} \mathrm{L}-1)$, ácido amino-oxiacético - AOA $\left(1 \mathrm{mg} \mathrm{L}^{-1}\right)$ e 1-metilciclopropeno - 1-MCP $\left(1 \mathrm{mg} \mathrm{L}^{-1}\right)$ durante 0 armazenamento por cinco semanas a $25^{\circ} \mathrm{C} \mathrm{e} 90 \%$ de umidade relativa. Foram avaliadas as variáveis: perda de massa, número e comprimento de brotações, atividade das enzimas peroxidase e polifenoloxidase, açúcares solúveis totais, amido, antocianinas, flavonois, teor de malonaldeído e proteínas totais. Durante o armazenamento a perda de massa, número e comprimento de brotações foram menores em raízes tratadas com AOA e 1-MCP. A atividade das enzimas peroxidase e polifenoloxidase foi maior em raízes tratadas com etileno. Os açúcares solúveis totais aumentaram e os teores de amido reduziram em todos os tratamentos. Os níveis de antocianinas e proteínas totais reduziram, enquanto os de flavonois e malondialdeído aumentaram durante 0 armazenamento. A brotação foi controlada em raízes tratadas com AOA e 1-MCP, prolongando a vida útil e melhorando 0 potencial de comercialização.

Palavras-chave: carboidratos; etileno; Ipomoea batatas; decadência da raiz; controle da brotação 


\section{Introduction}

Sweet potato has wide adaptability to the tropical environment, where Brazil stands out as the main producer in the Latin American continent, with emphasis on human nutrition, industrialization, animal feed and fuel alcohol production (Cavalcante et al., 2009; Foloni et al., 2013). Its consumption is mainly due to the composition of the roots rich in carbohydrates, minerals, vitamins and antioxidants, source of dietary fiber, carotenoids and anthocyanins (Musilová et al., 2017).

Despite the growing importance due to increased consumption and market value, sweet potato roots have a short postharvest shelf life, of about two to four weeks at room temperature. The economic losses of sweet potato during the postharvest chain are estimated from 35\% to 95\% in most developing countries. These losses are attributed mainly to decay and weight loss. In addition, the dormancy period is readily abbreviated by storage under favorable growth conditions, followed by excessive sprout growth, which reduces the marketable value; nevertheless, any information on sprout control is very limited (Rees et al., 2003; Cheema et al., 2013; Amoah \& Terry, 2018).

At sprouting, there is a highly dynamic hormonal crosstalk, affected by endogenous factors related to the development of cell and tissue specificity (Van de Poel et al., 2015). Ethylene regulates many physiological and biochemical mechanisms in plant tissues, including growth, cell division and cell expansion (Dubois et al., 2018). Continuous presence of ethylene may be an alternative to control potato and sweet potato sprouting. However, so far, there is no conclusive explanation regarding the mechanism by which continuous exogenous ethylene slows sprout growth (Cheema et al., 2013; Amoah et al., 2016; Foukaraki et al., 2016a, 2016b).

1-Methylcyclopropene (1-MCP) blocks the ethylene action by binding to its receptor on the cell membrane (In et al., 2013). The effects of 1-MCP on fruits and vegetables include prolonging shelf life, preventing physiological disorders, such as the development of superficial scalding in 'd'Anjou' pears (Yuab et al., 2017), and control of senescence by inhibiting the production of ethylene in durian fruits - Durio zibethinus (Amornputtia et al., 2016). Furthermore, the application of 1-MCP can also control sprouting in potato and sweet potato (Cheema et al., 2013; Foukaraki et al., 2016b).

Amino-oxyacetic acid (AOA) inhibits 1-carboxylic acid1-aminocyclopropane synthase (ACC synthase), considered limiting enzyme of ethylene biosynthesis, by competing for the binding with pyridoxamine 5'-phosphate on the active site of the enzyme (Mathooko et al., 2001). AOA inhibits the ethylene production and increases antioxidant activity in carnation petals, indicating various physiological functions (Karimi et al., 2012).

In most regions of Brazil, the storage and distribution of sweet potato roots occurs at room temperature and these conditions accelerate sprouting and root decay considerably, compromising the marketing value of the roots. Thus, the study reported here investigated the effects of ethylene, AOA and 1-MCP on weight loss, sprouting, decay and physiology of sweet potato roots cv. BRS Rubissol during storage.

\section{Material and Methods}

Sweet potato seedlings cv. BRS Rubissol were acquired from Frutplan (Pelotas, Rio Grande do Sul, Brazil). They were cultivated following standard commercial practices $\left(100 \mathrm{~g} \mathrm{~m}^{-2}\right.$ of limestone; at planting fertilization with $100 \mathrm{~g} \mathrm{~m}^{-2}$ of NPK 8-28-16 and $50 \mathrm{~g} \mathrm{~m}^{-2}$ of NPK 8-28-16 every 30 days). Irrigation was performed using sprinkler system when needed during six months in the experimental field of Federal University of Viçosa (UFV), Viçosa, Minas Gerais, Brazil (2045'20'S and $42^{\circ} 52^{\prime} 40^{\prime \prime} \mathrm{W}, 651 \mathrm{~m}$ of altitude).

The harvest was manual and roots free of apparent damage and disease were standardized by mass between 300 $700 \mathrm{~g}$. Root curing was done in B.O.D incubators at $30^{\circ} \mathrm{C}$ and $90 \%$ relative humidity for 7 days (Amoah et al., 2016).

The following treatments proposed by Cheema et al. (2013) were applied in the roots, with some adaptations: control (air); fumigation with $1 \mathrm{mg} \mathrm{L}^{-1}$ of 1-MCP (SmartFresh', Rohm and Haas, Pennsylvania, USA) in 90 L sealed chamber for 24 hours; immersion of the roots in $1 \mathrm{mg} \mathrm{L}^{-1}$ of AOA solution (SigmaAldrich, Missouri, USA) for 1 hour and subsequent drying with absorbent paper; injection of $10 \mu \mathrm{L} \mathrm{L}^{-1}$ of ethylene in $90 \mathrm{~L}$ and kept in sealed chamber for 48 hours. The roots were stored in B.O.D incubators at $25^{\circ} \mathrm{C}$ and $90 \%$ relative humidity.

The accumulated fresh mass loss was determined in an analytical balance of $1200 \mathrm{~g}$ with $0.1 \mathrm{~g}$ accuracy (Bel Engineering M1003), with the results expressed as percentage. The cumulative root decay was determined according Amoah et al. (2016), and the results were expressed in percentage. The number of sprouts was determined considering sprouts larger than $1 \mathrm{~mm}$ and the results expressed as number of sprouts per root. Sprouts length was measured with a digital caliper and the results expressed as $\mathrm{mm}_{\text {root }}{ }^{-1}$.

Peroxidase activity was based on a modified method described by Khan \& Robinson (1994), wherein $0.1 \mathrm{ml}$ of enzyme extract from the root flesh was added to the reaction medium containing $0.5 \mathrm{ml}$ of hydrogen peroxide $(1.80 \%)$, $0.5 \mathrm{~mL}$ of guaiacol (1.68\%), $0.4 \mathrm{ml}$ of deionized water and $1.5 \mathrm{ml}$ of $0.1 \mathrm{M}$ phosphate buffer ( $\mathrm{pH}$ 6.0). Polyphenol oxidase activity was based on a modified method described by Benjamin \& Montgomery (1973), where in $0.1 \mathrm{ml}$ of enzyme extract from the root flesh was added to the reaction medium containing $0.5 \mathrm{ml}$ of catechin $(5 \mathrm{mM}), 0.9 \mathrm{~mL}$ of deionized water and $1.5 \mathrm{~mL}$ of $0.1 \mathrm{M}$ phosphate buffer $(\mathrm{pH}$ 4.5). The reactions were quantified based on the alteration of the absorbance in UV-1601 spectrophotometer (Shimadzu, Kyoto, Japan), at wavelength of $470 \mathrm{~nm}$ (peroxidase) and 420 $\mathrm{nm}$ (polyphenoloxidase) at $25^{\circ} \mathrm{C}$, for 3 minutes. The activity was expressed as absorbance units (AU) $\mathrm{min}^{-1} \mathrm{mg}^{-1}$ protein. The total protein concentration was determined in the crude extract using bovine serum albumin as standard (Bradford, 1976). 
The total soluble sugars (TSS) were extracted from the root flesh with $80 \%$ ethanol at $65^{\circ} \mathrm{C}$ and the quantification was carried out by the phenol-sulfuric method (Dubois et al., 1956) using $0.02 \%$ sucrose as the standard solution, the reading was done at $490 \mathrm{~nm}$ and the results expressed as percentage of fresh mass. The residues obtained during extraction of TSS were dried at $70^{\circ} \mathrm{C}$ and hydrolyzed with $52 \%$ perchloric acid for quantification the of starch content. The quantification was carried out by the phenol-sulfuric method (Dubois et al., 1956) using $0.02 \%$ sucrose as the standard solution, the reading was done at $490 \mathrm{~nm}$, with obtained values multiplied by the correction factor 0.9 , and results expressed as percentage of dry mass, readings were taken in Genesys 10S UV-VIS spectrophotometer (Thermo Scientific, Massachusetts, USA).

Extraction of skin anthocyanins and flavonols was done under dark environment with $95 \%$ ethanol and $1.5 \mathrm{M}$ hydrochloric acid in the ratio $85: 15$. The quantification was in Genesys 10S UV-VIS spectrophotometer at wavelengths of 532 $\mathrm{nm}$ (anthocyanins), $374 \mathrm{~nm}$ (flavonols) and $653 \mathrm{~nm}$ (maximum absorbance of chlorophyll). The results were expressed as $\mu \mathrm{g}$ anthocyanins/flavonols $\mathrm{g}^{-1} \mathrm{MF}$ by equations 1 and 2 (Murray \& Hackett, 1991):

$$
\text { Anthocyanin content }\left(\mu \mathrm{g} \mathrm{mL}^{-1}\right)=\mathrm{A}_{532}-0.24 \cdot \mathrm{A}_{653}
$$

$$
\text { Flavonols content }\left(\mu \mathrm{g} \mathrm{mL} L^{-1}\right)=\mathrm{A}_{374}-0.24 \cdot \mathrm{A}_{653}
$$

The malondialdehyde content (MDA) from the root flesh was determined using thiobarbituric acid method (Hodges et al., 1999). Readings were taken on Genesys $10 \mathrm{~S}$ UV-VIS spectrophotometer at $520 \mathrm{~nm}$ for specific absorbance and $600 \mathrm{~nm}$ for non-specific absorbance. The MDA concentration was based on the equation 3 .

$$
\begin{aligned}
\mathrm{ABS}= & \left\{\left[\left(\mathrm{Abs}_{532}+\mathrm{TBA}\right)-\left(\mathrm{Abs}_{600}+\mathrm{TBA}\right)\right]-\right. \\
- & {\left.\left[\left(\mathrm{Abs}_{532}-\mathrm{TBA}\right)-\left(\mathrm{Abs}_{600}-\mathrm{TBA}\right)\right]\right\} } \\
\text { MDA content } & =\{\{[(\mathrm{ABS} / 155) \times 2] \times(\mathrm{CV} / \mathrm{V})\} / \mathrm{MF}\} \times \\
& \times 1000=\mathrm{nmol} \mathrm{g}^{-1} \mathrm{FM}
\end{aligned}
$$

where: TBA = thiobarbituric acid; $155 \mathrm{mM}^{-1} \mathrm{~cm}^{-1}=$ extinction coefficient of the MDA-TBA at $532 \mathrm{~nm} ; \mathrm{CV}=$ centrifuged volume $(\mathrm{mL}) ; \mathrm{SV}=$ sample volume $(\mathrm{mL}) ; \mathrm{FM}=$ fresh mass $(\mathrm{g})$.

Data were analyzed in split plot scheme, wherein the parcels correspond to the treatments and sub-plots to storage times (0, 1, 2, 3, 4 and 5 weeks), in a randomized block design with five replicates, the experimental unit was composed of a root. The results were submitted to regression analysis, where the models were chosen based on the significance of the regression coefficients and the biological phenomenon. The treatment means were compared with the control by the Dunnett test at $5 \%$ probability. Statistical analyzes were carried out using statistical Sisvar 5.6 software and the graph design was made in SigmaPlot 10.0 software.

\section{Results and Discussion}

Accumulated fresh mass loss, number and length of sprouts, and root decay increased during storage in all evaluated treatments (Figures 1A, 1B, 1C and 1D). However, these variables were significantly reduced due to the 1-MCP and $A O A$ application, and by the fifth storage week these treatments showed reductions of 13 and 18\%; 69 and 70\%; 70 and $81 \%$; and 60 and $50 \%$ in accumulated fresh mass loss, number and lengths of sprouts and root decay, respectively, when compared to control.

The accumulated fresh mass loss was low in all evaluated treatments, probably due to the root curing process, but it was related to the incidence of sprouting, since respiration and evaporation increase rapidly with the onset of sprouting and continuous sprout growth, resulting in a rapid mass loss increase on stored roots and impairing the nutritional status and quality aspects of products (Mani et al., 2014). Cheema et al. (2013) also observed relation between mass loss and sprouting when evaluating sweet potato roots of cultivars 'Bushbuck' and 'Ibees', having greater fresh mass losses and number of sprouts in the control and lower in 1-MCP treatment.

The use of ethylene inhibitors was efficient in inhibiting sprouting (Figure 2), because ethylene regulates some processes related to cell stretching, such as cytoskeletal rearrangement, cell wall relaxation and water uptake to establish turgor pressure (Van de Poel et al., 2015).

The effects of ethylene accumulation on cell division and cell expansion can be either positive or negative, depending on the environmental context and the organ (Dubois et al, 2018). It was demonstrated that continuous exposure to ethylene inhibits sprout stretching in sweet potato (Cheema et al., 2013; Amoah et al., 2016). The use of ethylene in potato $\mathrm{cv}$. 'Marfona' showed an increase in the endogenous concentration of abscisic acid (ABA), suggesting an explanation for the inhibition of sprout growth (Foukaraki et al., 2016a). In sweet potato cv. 'Covington', ethylene continuous supplementation reduced levels of endogenous $A B A$ and increased levels of cytokinins (zeatin riboside), without sprouts growth. The authors suggested the presence of a cytokinin sequestering substance (cytokinin riboside phosphorylase) acting during ethylene exposure, while a single application ethylene stimulated sprouting (Amoah et al., 2016).

Although ethylene inhibits sprout growth in sweet potato, there is growing evidence that it promotes both weight loss and decay (Amoah et al., 2016). Generally, two distinct types of root decay were observed: tip (proximal) rot and end (distal) rot. Both types of rot initiated from the respective root ends and progressed through the middle to the opposite ends (Amoah \& Terry, 2018). As observed in this study, 1- 


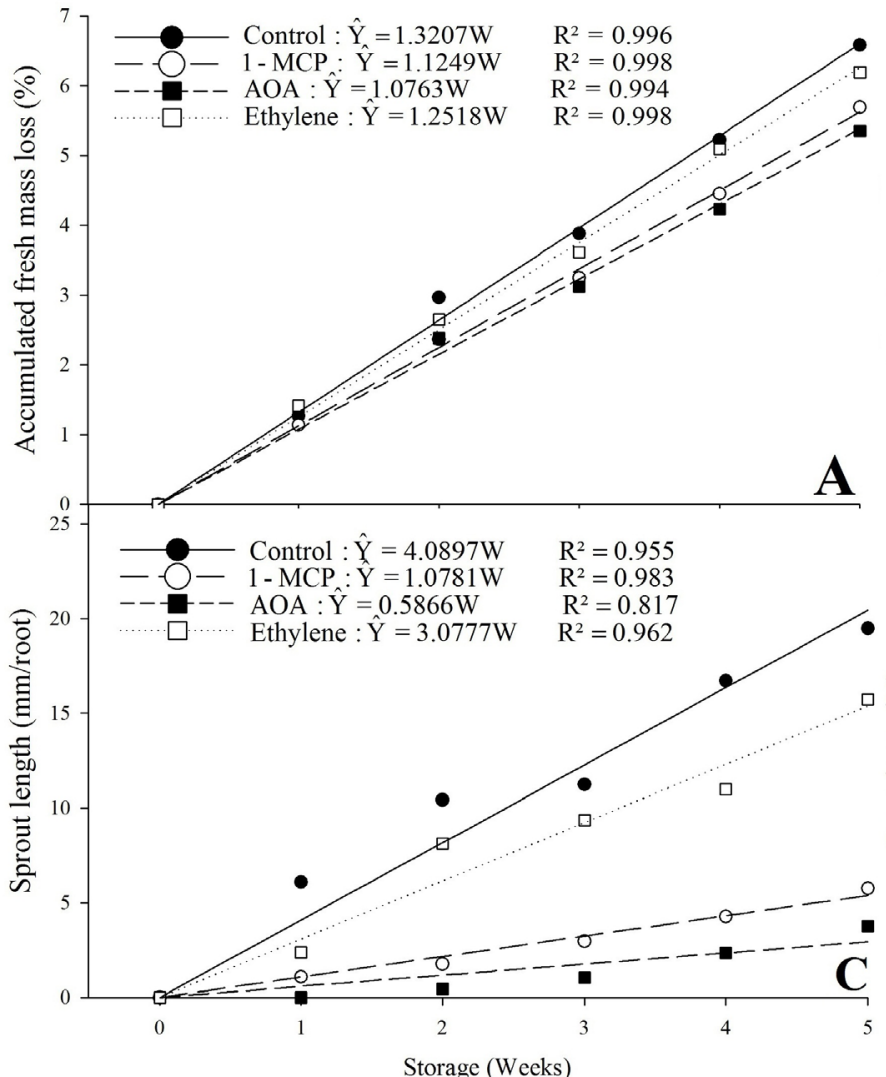

Figure 1. Fresh mass loss $(A)$, root decay $(B)$, number of sprouts stored for five weeks at $25^{\circ} \mathrm{C}$.

MCP and AOA may therefore be expected to counteract ethylene-induced decay (Figure $1 B$ and Figure 2). Cheema et al. (2013) found no diseases when 4-week-old sweet potato cvs. 'Bushbuck' and 'Ibees' were treated with 1-MCP and AOA during storage at $25^{\circ} \mathrm{C}$ for only 4 weeks. Amoah \& Terry (2018) reported that 1-MCP treatment may have an anti-decay effect and reduce weight loss.

The activities of peroxidase (POD) and polyphenoloxidase (PPO) showed linear increases during storage in all evaluated treatments (Figures $3 \mathrm{~A}$ and $3 \mathrm{~B}$ ). Increases in POD and PPO activities are due to biodegradation reactions related to the senescence and decay processes of sweet potatoes roots (Tang

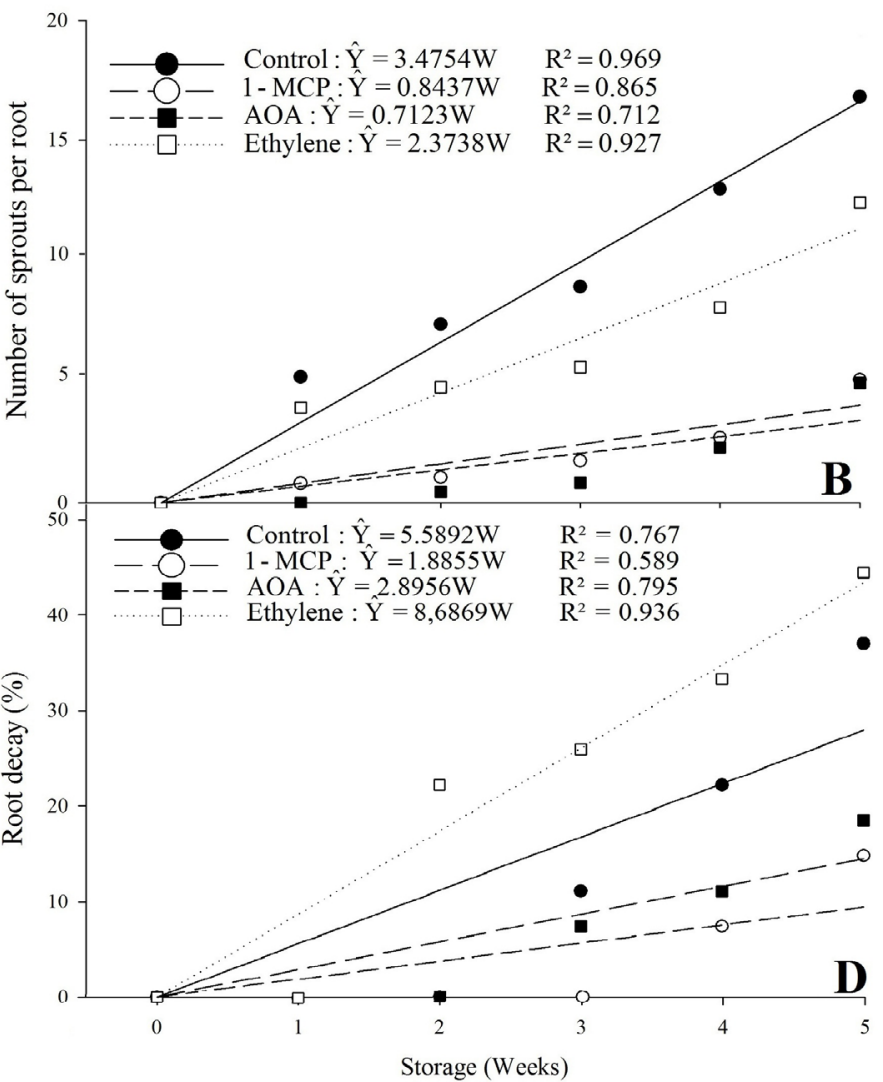

(C) and sprouts length (D) of sweet potato roots (BRS Rubissol) et al., 2014). The highest values were obtained from ethylene treated roots during storage because the ethylene potentiates the accumulation of reactive oxygen species (ROS), increasing POD and PPO activities during tissue stress responses (Xia et al., 2015). The major activity of antioxidant enzymes may be related to the process of root decay. In sweet potato roots, cV. 'Beauregard' (B-14) ethylene supplementation increased the process of root rot during storage at $18.3^{\circ} \mathrm{C}$ (Arancibia et al., 2013).

Total soluble sugars (TSS) increased up to the fourth week, followed by decreases up to the fifth week of storage in all evaluated treatments (Figure 4A). Increases in TSS up to the

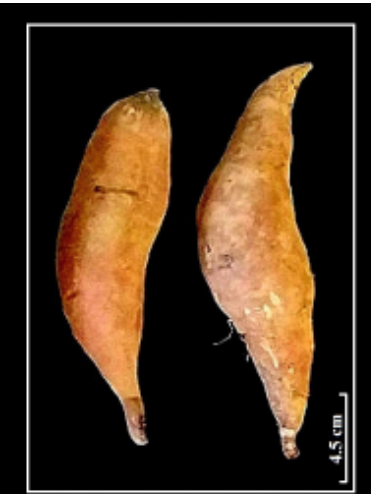

Initial Control

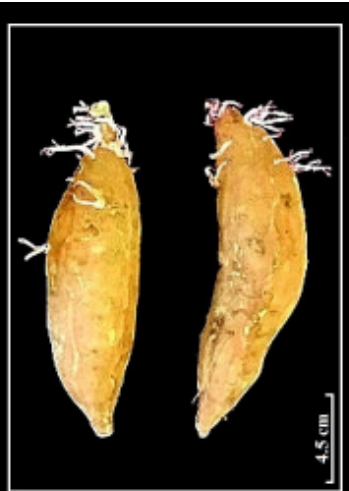

Control after five weeks

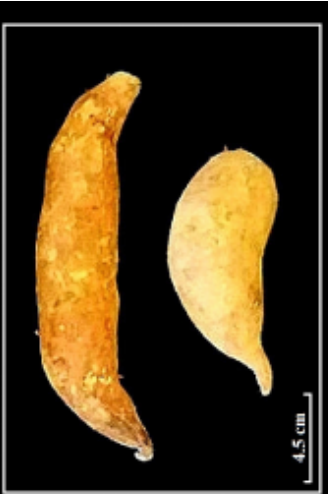

1-MCP treatment after five weeks

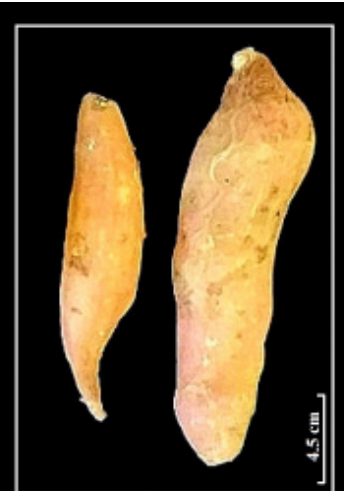

AOA treatment after five weeks

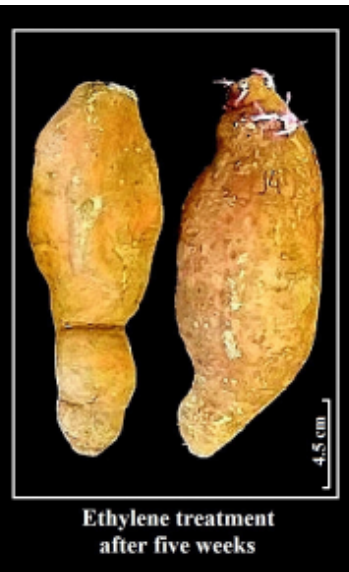

Figure 2. Sweet potato roots appearance (BRS Rubissol) before and after being stored for five weeks at $25^{\circ} \mathrm{C}$, depending on the applied treatments (Control, 1-MCP, AOA and ethylene). 

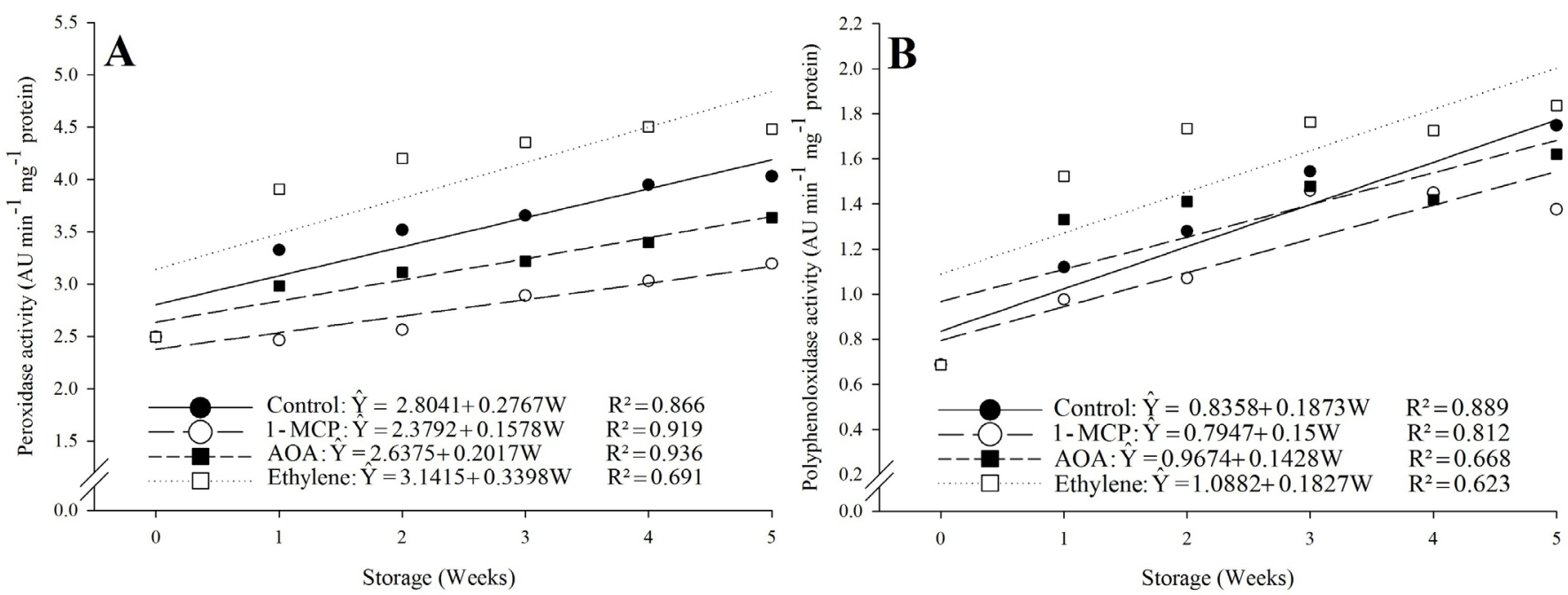

Figure 3. Peroxidase activity (A) and polyphenoloxidase activity (B) of sweet potato roots (BRS Rubissol) stored for five weeks at $25^{\circ} \mathrm{C}$.

fourth week of storage may be due to lower hydrolysis and higher synthesis of sucrose by enzymes sucrose-phosphate synthase (which converts UDP-glucose and fructose-6phosphate into sucrose-6-phosphate) and sucrose-phosphate phosphatase (which converts sucrose-6-phosphate into sucrose). Moreover, the decrease shown in the fifth storage week may be associated with sucrose-cleaving enzymes to generate energy for cell expansion and biosynthetic processes, such as invertases, converting sucrose into glucose and fructose and sucrose synthase, which converts sucrose into UDP-glucose and fructose (Wind et al., 2010).

$A B A$ and sucrose play important roles in sprout control, but biochemical and molecular factors are also involved. Sucrose acts as a signaling molecule for the control of hormonal dormancy and increases in mobilization of sucrose to meristem occur prior to dormancy interruption (Foukaraki et al., 2016a).

The starch content reduced during storage in all evaluated treatments (Figure 4B). The increase of sucrose demand in the sprouts development and respiratory processes causes

reductions in the levels of soluble sugars in the parenchyma cells, and can act as a signal to trigger the starch degradation to supply assimilates (Hajirezaei et al., 2003). Thus, the reductions in starch contents are related to senescence and decay processes, which increase starch degradation and were negatively correlated with total soluble sugars (Hu et al., 2016).

Anthocyanins contents decreased during storage in all evaluated treatments (Figure 5A). This result is due to deterioration processes during storage that were positively correlated with enzymes activity of $\beta$-glucosidase ( $\beta-G L C)$, polyphenoloxidase (PPO) and peroxidase (POD), which are mainly responsible for the degradation of anthocyanins, these may become gradually less intense due to saturation loss and/or change tonality by the formation of degradation compounds (Marszalek et al., 2017).

The content of flavonols increased during storage in all evaluated treatments (Figure 5B). The increases are due the ability of flavonols to detoxify ROS produced by oxidative stress. It has been reported that quercetin is a better
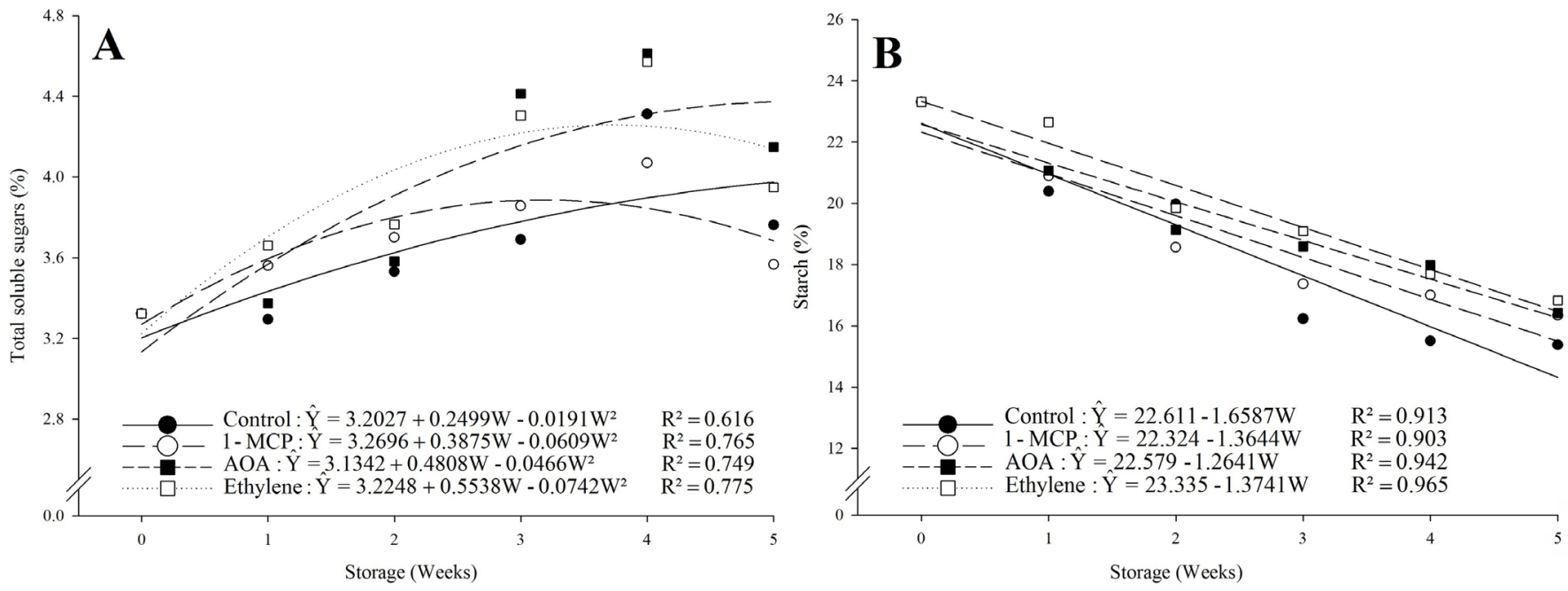

Figure 4. Total soluble sugars (A) and starch (B) of sweet potato roots (BRS Rubissol) stored for five weeks at $25^{\circ} \mathrm{C}$. 

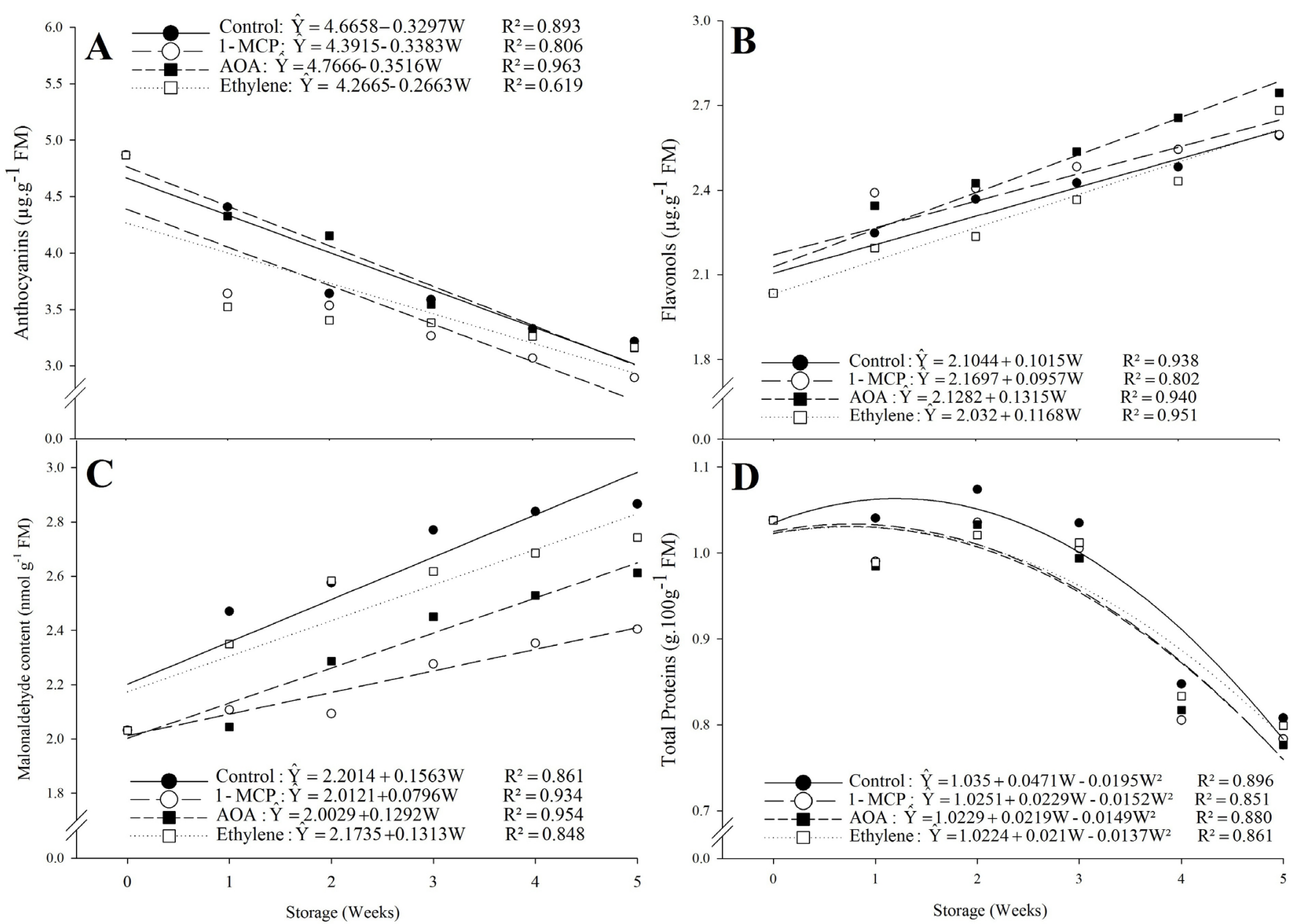

Figure 5. Anthocyanins (A), flavonols (B), malondialdehyde content (C) and total proteins (D) of sweet potato roots (BRS Rubissol) stored for five weeks at $25^{\circ} \mathrm{C}$.

superoxide scavenger than kaempferol, whereas the ability of kaempferol to scavenge hydroxyl radicals is better than that of quercetin (Markovic et al., 2014).

The malondialdehyde contents (MDA) increased during storage in all evaluated treatments (Figure $5 \mathrm{C}$ ). The highest values were shown in control and in ethylene treated roots due to the higher sprouting rate during storage, which leads to lower membranes stability, leading to higher leakage solutes rates (Kumar et al., 2014).

Lipid peroxidation is a common consequence of oxidative stress, promoting electrolyte leakage and MDA accumulation, which are indicators of oxidative stress (Li et al., 2018). Lipid metabolism, such as unsaturated fatty acids biosynthesis and glycerophospholipid metabolism, is very important for reduce cell membrane damage and improve the storage of sweet potato roots (Ji et al., 2017).

The total proteins increased until the second week and then decreased in all evaluated treatments (Figure 2A). The reductions are related to the sporamin degradation, which are storage proteins with trypsin inhibitory activity on sweet potato and represent $85 \%$ of the soluble proteins of the storage roots, in which its degradation provides nutritional resources for sprout growth (Liu, 2017).

Table 1 shows the results of the analyzed variables, comparing the applied treatments to the reference level
Table 1. Means of fresh mass loss (\%), root decay (\%), number of sprouts per root, sprouts length $(\mathrm{mm} / \mathrm{root})$, peroxidase activity - POD (AU $\mathrm{min}^{-1} \mathrm{mg}^{-1}$ protein), polyphenoloxidase activity - PPO (AU $\mathrm{min}^{-1} \mathrm{mg}^{-1}$ protein), total soluble sugars (\%), starch (\%), anthocyanins ( $\mu \mathrm{g} \cdot \mathrm{g}^{-1} \mathrm{FM}$ ), flavonols ( $\left.\mu \mathrm{g} \cdot \mathrm{g}^{-1} \mathrm{FM}\right)$, malonaldehyde content - MDA (nmol.g ${ }^{-1} \mathrm{FM}$ ) and total proteins $\left(\mathrm{g} \cdot 100 \mathrm{~g}^{-1} \mathrm{FM}\right)$ in sweet potato roots (BRS Rubissol) stored for five weeks at $25^{\circ} \mathrm{C}$, depending on the applied treatments.

\begin{tabular}{lcccc}
\hline \multicolumn{1}{c}{ Analyzes } & Control & 1-MCP & AOA & Ethylene \\
\hline Fresh mass loss & 3.19 & $2.64^{* *}$ & $2.59^{* *}$ & 3.00 \\
\hline Number of sprouts & 8.86 & $1.68^{*}$ & $0.91^{*}$ & $5.76^{*}$ \\
\hline Sprouts length & 10.72 & $2.67^{*}$ & $0.92^{*}$ & $7.22^{*}$ \\
Root decay & 11.73 & $3.70^{*}$ & $6.17^{*}$ & $20.98^{*}$ \\
\hline POD activity & 3.49 & $2.70^{*}$ & 3.14 & $3.99^{* *}$ \\
PPO activity & 1.27 & 1.12 & 1.30 & 1.49 \\
\hline Total soluble sugars & 3.65 & 3.67 & 3.90 & 3.93 \\
Starch & 18.46 & 18.91 & 19.42 & 19.90 \\
Anthocyanins & 3.84 & 3.54 & 3.88 & 3.59 \\
Flavonols & 2.35 & 2.41 & 2.46 & 2.32 \\
\hline MDA content & 2.59 & 2.21 & 2.33 & 2.50 \\
\hline Total proteins & 0.97 & 0.94 & 0.94 & 0.95 \\
\hline
\end{tabular}

Means with asterisks differ significantly from the control on the same line by Dunnett's test at $5 \%$ probability $\left({ }^{*} p<0.05 ;{ }^{*} p<0.01\right)$.

(control). Significant changes were observed in the fresh mass loss, number and length of sprouts, root decay and peroxidase 
activity. Treatments with 1-MCP and AOA showed the lowest fresh mass loss, number and length of sprouts and root decay. The ethylene and 1-MCP treatments showed the highest and lowest peroxidase activity, respectively.

Both the market value associated with the product and the economic losses in sweet potato postharvest are attributed mainly to sprouting, decay and weight loss. According to the data, in the third week of storage, the commercial quality of control and ethylene treatment was very poor; therefore, AOA and 1-MCP are efficient treatments in reducing postharvest losses enabling sweet potatoes roots storage for up to five weeks at $25^{\circ} \mathrm{C}$, extending the shelf life up to $40 \%$.

In relation to the temporal flux and physiological aspects, only the variable peroxidase activity showed significant variations in relation to the applied treatment. Polyphenoloxidase activity, total soluble sugars, starch, anthocyanis, flavonols, malondialdehyde content and total proteins did not show significant variations among the evaluated treatments. Moreover, according to the biological phenomenon, the slight variations during storage did not promote physiological disorders, maintaining the consumption quality.

\section{Conclusions}

1-MCP and AOA treatments had an anti-decay effect by reducing sprouting and weight loss, with significant improvement in the shelf-life of the stored roots up to five weeks. The study reveals that ethylene treatment induced decay of sweet potato and 1-MCP minimizes peroxidase activity. The physiological quality was kept during storage, not having physiological disorders. Therefore 1-MCP and AOA treatments are better to improve marketing potential of tuberous sweet potato roots during storage at 25 으.

\section{Acknowledgment}

The authors are grateful to the National Council for Scientific and Technological Development (CNPq) for financial support.

\section{Literature Cited}

Amoah, R. S.; Terry, L. A. 1-Methylcyclopropene (1-MCP) effects on natural disease resistance in stored sweet potato. Journal of the Science of Food and Agriculture, v. 98, n. 12, p. 4597-4605, 2018. https://doi.org/10.1002/jsfa.8988.

Amoah, R.S.; Landahl, S.; Terry, L.A. The timing of exogenous ethylene supplementation differentially affects stored sweet potato. Postharvest Biology and Technology, v. 120, p. 92-102, 2016. https://doi.org/10.1016/j.postharvbio.2016.05.013.

Amornputtia, S.; Ketsaa, S.; Van Doornc, W.G. 1-Methylcyclopropene (1-MCP) inhibits ethylene production of durian fruit which is correlated with a decrease in ACC oxidase activity in the peel. Postharvest Biology and Technology, v. 114, p. 69-75, 2016. https://doi.org/10.1016/j.postharvbio.2015.11.020.
Arancibia, R.A.; Main, L.J.; Clark, C.A. Sweet potato tip rot incidence is increased by preharvest applications of ethephon and reduced by curing. HortTechnology, v. 23, n. 3, p. 288-293, 2013. https:// doi.org/10.21273/HORTTECH.23.3.288.

Benjamin, N.D; Montgomery, M.W. Polyphenol oxidase of royal ann cherries: purification and characterization. Journal of Food Science, v. 38, n.5, p. 799-806, 1973. https://doi. org/10.1111/j.1365-2621.1973.tb02079.x.

Bradford, M.M. A rapid and sensitive method for the quantitation of microgram quantities of protein utilizing the principle of proteindye binding. Analytical Biochemistry, v. 72, n. 1-2, p. 248-254, 1976. https://doi.org/10.1016/0003-2697(76)90527-3.

Cavalcante, M.; Ferreira, P.V.; Paixão, S.L.; Costa, J.G.; Pereira, R.G.; Madalena, J.A.S. Potenciais produtivo e genético de clones de batata-doce. Acta Scientiarum Agronomy, v. 31, n.3, p. 421-426, 2009. https://doi.org/10.4025/actasciagron.v31i3.835.

Cheema, M.U.A.; Reesa, D.; Colgana, R.J.; Taylorb, M.; Westbya, A. The effects of ethylene, 1-MCP and AVG on sprouting in sweetpotato roots. Postharvest Biology and Technology, v. 85, p. 89-93, 2013. https://doi.org/10.1016/j.postharvbio.2013.05.001.

Dubois, M.; Gilles, K.A.; Hamilton, J.K.; Rebers, P.A.; Smith, F. Colorimetric method for determination of sugars and related substances. Analytical Biochemistry, v. 28, n. 3, p. 350-356, 1956. https://doi.org/10.1021/ac60111a017.

Dubois, M.; Van Den Broeck, L.; Inzé, D. The Pivotal Role of Ethylene in Plant Growth. Trends in Plant Science, v. 23, n. 4, p. 311-323, 2018. https://doi.org/10.1016/j.tplants.2018.01.003.

Foloni, J.S.S.; Corte, A.J.; Corte, J.R.N.; Echer, F.R.; Tiritan, C.S. Adubação de cobertura na batata-doce com doses combinadas de nitrogênio e potássio. Semina: Ciências Agrárias, v. 34, n.1, p. 117126, 2013. https://doi.org/10.5433/1679-0359.2013v34n117.

Foukaraki, S.G.; Cools, K.; Chope, G.A.; Terry, L.A. Impact of ethylene and 1-MCP on sprouting and sugar accumulation in stored potatoes. Postharvest Biology and Technology, v. 114, p. 95-103, 2016b. https://doi.org/10.1016/j.postharvbio.2015.11.013.

Foukaraki, S.G.; Cools, K.; Terry, L.A. Differential effect of ethylene supplementation and inhibition on abscisic acid metabolism of potato (Solanum tuberosum L.) tubers during storage. Postharvest Biology and Technology, v. 112, p. 87-94, 2016 a. https://doi.org/10.1016/j.postharvbio.2015.10.002.

Hajirezaei, M.R.; Börnke, F.; Peisker, M.; Takahata, Y.; Lerchl, J.; Kirakosyan, A.; Sonnewald, U. Decreased sucrose content triggers starch breakdown and respiration in stored potato tubers (Solanum tuberosum). Journal of Experimental Botany, v. 54, n. 382, p. 477-488, 2003. https://doi.org/10.1093/jxb/erg040.

Hodges, D. M.; Delong, J. M.; Forney, C. F.; Prange, R. K. Improving the thiobarbituric acid-reactive-substances assay for estimating lipid peroxidation in plant tissues containing anthocyanin and other interfering compounds. Planta, v. 207, n. 4, p. 604-611, 1999. https://doi.org/10.1007/s004250050524.

Hu, X.; Kuang, S.; Zhang, A.D.; Zhang, W.S.; Chen, M.J.; Yin, X.R.; Chen, K.C. Characterization of starch degradation related genes in postharvest kiwifruit. International Journal of Molecular Sciences, v. 17, n. 12, article 2112, 2016. https://doi.org/10.3390/ ijms17122112. 
In, B.C.; Strable, J.; Binder, B.M.; Falbel, T.G.; Patterson, S.E. Morphological and molecular characterization of ethylene binding inhibition in carnations. Postharvest Biology and Technology, v. 86, p. 272-279, 2013. https://doi.org/10.1016/j. postharvbio.2013.07.007.

Ji, C.Y.; Ghung, W-H.; Kim, H.S.; Jung; W.Y; Kang, L.; Jeong, J.C.; Kwak, S-S. Transcriptome profiling of sweetpotato tuberous roots during low temperature storage. Plant Physiology and Biochemistry, v. 112, p. 97-108, 2017. https://doi.org/10.1016/j. plaphy.2016.12.021.

Karimi, M.; Hassanpour, A.; Zakizadeh, H. Increasing plant longevity and associated metabolic events in potted carnation (Dianthus caryophyllus L. Clove Pink). Brazilian Journal of Plant Physiology, v. 24 , n. 4 , p. 247-252, 2012. https://doi.org/10.1590/S167704202012000400003.

Khan, A.A.; Robinson, D.S. Hydrogen donor specifity of mango isoperoxidases. Food Chemistry, v. 49, n. 4, p. 407-410, 1994. https://doi.org/10.1016/0308-8146(94)90013-2.

Kumar, M.; Singh, V. P.; Arora, A.; Singh, N. The role of abscisic acid $(A B A)$ in ethylene insensitive gladiolus (Gladiolus grandiflora Hort.) flower senescence. Acta Plant Physiology, v. 36, n.1, p. 151-159, 2014. https://doi.org/10.1007/s11738-013-1395-6.

Li, X.; Yang, H.; Lu, G. Low-temperature conditioning combined with cold storage inducing rapid sweetening of sweetpotato tuberous roots (Ipomoea batatas (L.) Lam) while inhibiting chilling injury. Postharvest Biology and Technology, v. 142, p. 1-9, 2018. https:// doi.org/10.1016/j.postharvbio.2018.04.002.

Liu, Q. Improvement for agronomically important traits by gene engineering in sweetpotato. Breeding Science, v. 67, n.1, p. 1526, 2017. https://doi.org/10.1270/jsbbs.16126.

Mani, F.; Bettaieb, T.; Doudech, N.; Hannachi, C. Physiological mechanisms for potato dormancy release and sprouting: a review. African Crop Science Journal, v. 22, n. 2, p. 155-174, 2014. https:// www.ajol.info/index.php/acsj/article/viewFile/104945/94994. 02 Sep. 2018.

Markovic, J.M.D.; Milenkovic, D.; Amie, D.; Popovic-Biijelic, A.; Mojovic, M.; Pasti, I.A.; Markovic, Z.S. Energy requirements of the reactions of kaempferol and selected radical species in different media: towards the prediction of the possible radical scavenging mechanisms. Structural Chemistry, v. 25, n. 6, p. 1795-1804, 2014. https://doi.org/10.1007/s11224-014-0453-z.

Marszalek, K.; Wozniak, L.; Kruszewski, B.; Skapska, S. The Effect of High Pressure Techniques on the Stability of Anthocyanins in Fruit and Vegetables. International Journal of Molecular Sciences, v. 18, n. 2, article 277, 2017. https://doi.org/10.3390/ ijms18020277.
Mathooko, F.M.; Tsunashima, Y.; Owino, W.Z.O.; Kubo, Y.; Inaba, A. Regulation of genes encoding ethylene biosynthesis enzymes in peach (Prunus persica L.) fruit by carbon dioxide and 1-methylcyclopropene. Postharvest Biology and Technology, v. 21 , n. 3, p. 265-281, 2001. https://doi.org/10.1016/S09255214(00)00158-7.

Murray, J.R.; Hackett, W.P. Dihydroflavonol reductase activity in relation to differential anthocyanin accumulation in juvenile and mature phase Hedera helix L. Plant Physiology, v. 97, n. 1, p. 343351, 1991. https://doi.org/10.1104/pp.97.1.343.

Musilová, J.; Bystrická, J.; Árvay, J.; Harangózo, L. Poliphenols and phenolic acids in sweet potato (Ipomoea batatas L.) roots. Potravinarstvo Slovak Journal of Food Sciences, v. 11, n. 1, p. 8287, 2017. https://doi.org/10.5219/705.

Rees, D.; van Oirschot, Q.; Kapinga, R.; Mtunba, K.; Chilosa, D.; Mbilinyi, M.B.; Rwiza, E.J.; Kilima, M.; Kiozya, H.; Amour, R.; Ndondi, T.; Chottah, M.; Mayona, C.M.; Mende, D.; Tomlins, K.I.; Aked, J.; Carey, E.E. Extending root shelf-life during marketing by cultivar selection. In: Rees, D.; van Oirschot, Q.; Kapinga, R. (Eds.). Sweetpotato post-harvest assessment: experiences from East Africa. Chatman: Natural Resources Institute, 2003, Chap.5, p. 51-66. http://www.sweetpotatoknowledge.org/wp-content/ uploads/2016/01/Extending-root-shelf-life-by-selection_book_ ch5.pdf. 05 Sep. 2018.

Tang, J.; Hu, K.D.; Hu, L.Y.; Li, Y.H.; Liu, Y.S.; Zhang, H. Hydrogen Sulfide acts as a fungicide to alleviate senescence and decay in fresh-cut sweet potato. HortScience, v. 49, n. 7, p. 938-943, 2014. https:// doi.org/10.21273/HORTSCI.49.7.938.

Van de Poel, B.; Smet, D.; Van der Straeten, D. Ethylene and hormonal cross talk in vegetative growth and development. Plant Physiology, v. 169, n. 1, p. 61-72, 2015. https://doi.org/10.1104/ pp.15.00724.

Wind, J.; Smeekens, S.; Hanson, J. Sucrose: metabolite and signaling molecule. Phytochemistry, v. 71, n. 14-15, p. 1610-1614, 2010. https://doi.org/10.1016/j.phytochem.2010.07.007.

Xia, X.J.; Zhou, Y.K.; Shi, K.; Zhou, J.; Foyer, C.H.; Yu, J.Q. Interplay between reactive oxygen species and hormones in the control of plant development and stress tolerance. Journal of Experimental Botany, v. 66, n. 10, p. 2839-2856, 2015. https://doi.org/10.1093/ jxb/erv089.

Yuab, J.; Wanga, Y. The combination of ethoxyquin, 1-methylcyclopropene and ethylene treatments controls superficial scald of 'd'Anjou' pears with recovery of ripening capacity after long-term controlled atmosphere storage. Postharvest Biology and Technology, v.127, p.53-59, 2017. https://doi.org/10.1016/j.postharvbio.2017.01.012. 